\title{
QUALITY ATTRIBUTES OF CITRUS FIBER ADDED GROUND BEEF AND CONSUMER ACCEPTANCE OF CITRUS FIBER ADDED TURKISH MEAT- BALLS
}

\author{
Ayça Gedikoğlu' ${ }^{10}$, Andrew Douglas Clarke ${ }^{\text {(D) }}$
}

\section{Cite this article as:}

Gedikoğlu, A., Clarke, A.D. (2019). Quality attributes of citrus fiber added ground beef and consumer acceptance of citrus fiber added Turkish meatballs. Food and Health, 5(4), 205-214. https://doi.org/10.3153/FH19022

\section{Konya Food and Agriculture University, Department of Food Engineering, Dede Korkut Mah. Beyşehir Cd. No: 9, Meram, Konya 42080, Turkey \\ 2 University of Missouri, Food Science Department, Columbia, MO 65211, USA}

ORCID IDs of the authors: A.Ç. 0000-0002-5105-141X A.D.C. 0000-0002-9263-0792

Submitted: 07.11 .2018

Accepted: 06.04.2019

Published online: 19.06 .2019

Correspondence:

Ayça GEDIKOĞLU

E-mail: ayca.gedikoglu@gidatarim.edu.tr

\begin{abstract}
The objectives of this study were (I) to determine the addition of different citrus fiber (CF) levels $(0 \%, 1 \%, 5 \%$, and $10 \%)$ on the quality attributes of ground beef meatballs, (II) to determine consumer preferences for ground beef meatballs made with different CF levels $(0 \%, 1 \%, 3 \%$ and $5 \%)$. Both water holding capacity and cooking yield of samples significantly $(\mathrm{p}<0.05)$ increased with addition of citrus fiber. There is no significant $(\mathrm{p}>0.05)$ difference found between the control $\mathrm{CF}$ $0 \%$ and the CF $1 \%$ for hardness and springiness values. Hunter color $L, a, b$ values were significantly $(\mathrm{p}<0.05)$ impacted by the addition of citrus fiber. Results of the consumer panel showed that CF $1 \%$ got the highest flavor score with 6.61 followed by CF $0 \%$ with 6.52 ( $p>0.05$ ). CF 5\% had the lowest texture scores with 5.46. Over all likeness was highest for control with 6.69 followed by CF $1 \%$ with $6.56, \mathrm{CF} 3 \%$ with 5.9 , and $\mathrm{CF} 5 \%$ with 5.47 . In conclusion, citrus fiber can be used in comminuted meat products at $1 \%$ level.
\end{abstract}

Keywords: Citrus Fiber, Meatballs, Water Holding Capacity, Flavor, Texture, Color

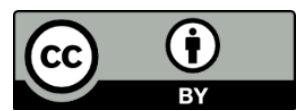

(C) Copyright 2019 by ScientificWebJournals

Available online at

http://jfhs.scientificwebjournals.com 


\section{Introduction}

In recent years consumers' food choices have shifted towards healthy foods due to increased incidence of coronary heart disease (CHD), diabetes, obesity and cancer (Rosamond et al., 2008). Food products associated with high fat content and high cholesterol have been linked to incidences of CHD (Micha, Wallace, \& Mozaffarian, 2010), diabetes mellitus (Lajous et al., 2011), and risk of stroke (Larsson, Virtamo, \& Wolk, 2011). Processed meat products have been closely linked to these diseases due to their high cholesterol content and saturated fat (Cross, Leitzmann, \& Gail, 2007; Micha et al., 2010). New food products have been developed to have high protein content, low fat content as well as high fiber content to provide healthier food alternatives to consumers. Plant based proteins such as legumes (Serdaroglu, Yildiz-Turp, \& Abrodimov, 2005) and soy protein (Singh, Kumar, Sabapathy, \& Bawa, 2008) have been studied as extenders to increase protein content and mimic or replace fats to reduce the use of saturated fat in meat products. Additionally, fiber has been studied for both health and functional benefits. It has been reported that consumption of fiber helps with decreased cholesterol levels, with the absorption of glucose (Scheneeman, 1987), and decreased incidence of hemorrhoids and colon cancer (Kritchersky, 1990). Also, dietary fiber such as psyllium and $\beta$-glucan have been approved by the Food and Drug Administration (FDA) for health claims for protection against coronary heart disease (USDHHS, 1997, 1998). It has been reported that insoluble fiber such as cellulose has been successfully used as a fat replacement in many food products such as frozen desserts, cheese spreads, salad dressing and processed meat products (Akoh, 1998). Functional properties of processed meat products made with different fiber sources have been studied. Use of peach fiber in low fat frankfurters (Grigelmo-Miguel, Motilva-Casado, \& Martin-Belloso, 1997), $\beta$-glucan rich fiber in breakfast sausage (Aleson-Carbonell, Fernandez-Lopez, Perez-Alvarez, \& Kuri, 2005), rice bran fiber in reduced fat frankfurters (Choi et al., 2010), orange fiber in fermented sausage called Sucuk (Yalinkilic, Kaban, \& Kaya, 2012), yellow passion fruit fiber in pork burgers (Lopez-Vargas, Fernandez-Lopez, PerezAlvarez, \& Viuda-Martos, 2014) and carrot and lemon fiber in low-fat beef hamburgers (Soncu et al., 2015) have been helpful for improving functional properties of meat products. According to Gorinstein et al. (2001), citrus peel (albedo and flavedo) is rich in soluble fiber and can be used in meat products as a functional ingredient. Also, it has been reported that due to citrus fiber high vitamin $\mathrm{C}$ content and presence of bioactive compounds such as phenolic acids and flavonoids, it may provide further benefits as an antioxidant (AlesonCarbonell et al., 2005; Fernandez-Lopez et al., 2004). Citrus fiber, by product of juice industry, provides great opportunity to be used as a fiber source and functional ingredient in comminuted meat products.

Based on this information, the objectives of our study were (I) to determine the impact of adding citrus fiber on the quality attributes of beef meatballs. The quality attributes investigated were the $\mathrm{pH}$ of both the raw and cooked meatballs, water holding capacity (WHC), cooking yield (\%), textural properties, Hunter color $L, a$, and $b$ values, and proximate composition. (II) to determine consumers' acceptance for flavor, texture and overall liking of ground beef meatballs made with citrus fiber.

\section{Materials and Methods}

\section{Sample Preparation}

Beef cattle were slaughtered and their carcasses placed in a cooler for 48 hours. Later, two bottom rounds were collected from the carcass and weighed. After cutting the beef bottom rounds into smaller pieces, they were two-step (course and fine) ground using a $\mathrm{LEM}^{\mathrm{TM}}$ Products $.35 \mathrm{P}$ stainless steel electric meat grinder (West Chester, $\mathrm{OH}$ ). Once they were ground, they were separated into four treatment groups and weighed. The treatment group with $0 \%$ citrus fiber, in other words control (CF 0\%) was made into ground beef meatballs using a 50-mm diameter ice cream scoop; the meatballs were placed onto four Styrofoam ${ }^{\circledR}$ trays for day 0 , day 3, day 6 , and day 9, and were covered with stretch film and labeled for replication, treatment group, and experimental days. Packages were then placed into a refrigerator. Treatments of $1 \%$, $5 \%$, and $10 \%$ citrus fiber were weighed based on the ground beef weight, and the fiber was mixed into the ground beef using a KitchenAid ${ }^{\circledR}$ blender. After each mixing, the blender was cleaned before mixing the next treatment group. Later, meat from each group was also made into meatballs using a 50-mm diameter ice cream scoop. The meatballs were placed onto Styrofoam ${ }^{\circledR}$ trays covered with stretch film, and labeled for replication, treatment group, and experimental days. Packages were placed into the refrigerator until their use in the experiment. This procedure was replicated two more times on different slaughtering days to provide three total replications. 


\section{pH}

A $5 \mathrm{~g}$ sample was homogenized with $45 \mathrm{~mL}$ distilled water by using a blender. Then, the $\mathrm{pH}$ of the slurry was determined by using a Fisher Accumet $^{\circledR}$ model 230A pH/ion meter (Fisher Scientific Inc., Salt Lake City, UT). The pH measurements of both the raw and cooked samples of the three replicates were determined in duplicates.

\section{Water Holding Capacity}

The water holding capacity of the samples was determined according to methods reported by (Wierbicki, 1958). The formula used to calculate the water holding capacity (WHC) is shown below (Price and Schweigert, 1987); WHC was determined in triplicate for each treatment. Lower values indicate better water holding capacity.

\section{$\mathrm{WHC}=\left[\frac{\text { Area of free water }}{\text { Area of meat }}\right]$}

\section{Cooking Yield}

The cooking yield of the ground beef meatballs was calculated by using the formula shown below (Bishop et al., 1993).

$$
\text { Cooking Yield \% }=\left[\frac{\text { Cooked weight of the product }}{\text { Uncooked weight of the product }}\right] *
$$

\section{Determination of Moisture, Fat and Protein Content}

The moisture and fat content of the meat samples was determined based on the CEM SMART Trac system. This twostep system uses microwave for determining the moisture content of a meat sample. Next, it uses nuclear magnetic resonance (NMR) analysis for determining a fat content of the microwaved sample (Keeton et al., 2003). The protein content was determined using bicinchoninic acid (BCA) colorimetric detection and quantitation of the total protein method, according to Smith et al. (1985).

\section{Texture Profile Analysis}

After ground beef meatballs were cooked and their weight was recorded for the cooking yield procedure, they were cooled to room temperature before texture profile analysis (TPA). Each meatball was compressed to 50 percent of its original height in two consecutive cycles at a crosshead speed of $50 \mathrm{~mm} / \mathrm{min}$ by using a TA-TX2 texture analyzer (Stable Micro Systems, Surrey, UK) with a 38-mm diameter probe for the evaluation of the texture profile analysis, as described by Bourne (1978). Triplicates of each treatment were evaluated for hardness, springiness, cohesiveness, gumminess, chewiness, and resilience.

\section{Hunter Color Values}

Hunter color $L$ (lightness), $a$ (redness) and $b$ (yellowness) values were evaluated using a Minolta colorimeter (Konica Minolta Chroma Meter CR-410, Minolta Ltd., Milton Keynes, UK). The raw ground beef treatments were placed onto Styrofoam ${ }^{\circledR}$ trays individually, and treatments were spread flat on the tray to provide an even surface for color measurement. The Minolta colorimeter was placed directly on the surface of the ground beef samples. Color values were measured in triplicate for each treatment.

\section{Consumer Survey}

\section{Meatball Manufacture}

Ground beef (with 90\% meat and 10\% fat) and other ingredients were bought fresh from a store the day before the consumer panel. A Turkish köfte recipe was used for the formulation of the meatballs, and this recipe produced approximately 35-40 small meatballs. Table 1 shows the formulation of control (CF $0 \%$ ) treatment of ground beef meatballs. The rest of the treatments were made the same way with the exception of the addition of citrus fiber in $1 \%, 3 \%$ and $5 \%$ levels. After establishing the four ground beef foundations, onion and garlic were peeled and parsley leaves were picked; they were washed, diced and chopped. Ground beef and other ingredients were all mixed together. The meatballs were made using a 36-mm diameter ice cream scoop to make sure that all the meatballs were the same size. Meatballs were placed on a tray with a rack and each rack had a label with the treatment name on it. Once all the meatballs of a treatment were placed on a rack, the tray was placed in an oven, which was preheated to $190^{\circ} \mathrm{C}$. A probe was placed into one of the meatballs and the temperature was set up for $72^{\circ} \mathrm{C}$. Once the meatballs were properly cooked, the tray was taken out from the oven to cool down. The same procedure was followed for all the treatments. Meatballs were placed into labeled glass containers with lids for each treatment. Because the consumer panel room had only five available seats, the containers were kept in a refrigerator to insure safe handling practices between sets of panels. In order to serve warm meatballs to 
the panelists, the meatball treatments were placed in individual Crock-Pot slow cookers with tomato sauce. The temperature of the sauce was kept above $60^{\circ} \mathrm{C}$ to provide safe and warm meatballs to panelists, and verified by calibrated temperature probes. The recipe of the tomato sauce is shown in Table 1. Meatballs were removed from the refrigerator to the Crock-Pots as needed.

\section{Sensory Evaluation}

Untrained panelists (164) of students, faculty and staff of the University of Missouri volunteered to participate in the consumer taste panel. Each panelist evaluated four warm meatball samples. One whole meatball for each treatment was placed into a labeled plastic cup. Each treatment was coded with randomly selected 3-digit numbers, and the four treatments were served to panelists in a randomized order. Panelists were also provided with a glass of water and were instructed to cleanse their pallets before trying the next sample.
The rating test employed the hedonic scale of dislike extremely (1) to like extremely (9) (IFT, 1981). Panelists were instructed to evaluate the samples based on their degree of likeness for flavor, texture and overall likeness. Hedonic scale results were converted to numerical scores for statistical analysis.

\section{Statistical Analysis}

Three replications of ground beef meatballs were evaluated for cooking yields, WHC, pH, TPA, Hunter color values, and proximate analysis. Both data for quality attributes and consumer panel was analyzed by the analysis of variance (ANOVA), using the general linear model (GLM) procedure of the (SAS, 2011). Quality attributes data was randomized complete block design in which the block was a carcass. The treatments were arranged as a $4 \times 4$ factorial ( 4 levels of citrus fiber, 4 days). Means were separated by the Tukey test when significant $(p<0.05)$ treatment effects were found.

Table 1. List of ingredients for the Turkish meatball and the tomato sauce

\begin{tabular}{llll}
\hline $\begin{array}{l}\text { List of Ingredients for } \\
\text { Meatball }\end{array}$ & Weight (g) or Quantity & $\begin{array}{l}\text { List of Ingredients } \\
\text { for Tomato Sauce }\end{array}$ & Weight (g or ml) \\
\hline $\begin{array}{l}\text { Ground beef }(90 \% \\
\text { Lean })\end{array}$ & $454 \mathrm{~g}$ & Water & $1000 \mathrm{ml}$ \\
Onion & $240 \mathrm{~g}(1$ medium size $)$ & $\begin{array}{l}\text { Butter } \\
\text { Tomato paste }\end{array}$ & $227 \mathrm{~g}$ \\
Parsley & $12 \mathrm{~g}$ & $120 \mathrm{~g}$ \\
Garlic & $3 \mathrm{~g}(1$ and half garlic) & Dry mint flakes & $1 \mathrm{~g}$ \\
Egg & $46 \mathrm{~g}(1$ shelled egg $)$ & Black pepper & $0.8 \mathrm{~g}$ \\
Olive oil & $15 \mathrm{~g}$ & & \\
Pepper paste & $14 \mathrm{~g}$ & & \\
Salt & $2.3 \mathrm{~g}$ & & \\
Cumin & $2.2 \mathrm{~g}$ & & \\
Black pepper & $1.2 \mathrm{~g}$ & & \\
Sweet paprika & $1 \mathrm{~g}$ & & \\
Nutmeg & $0.8 \mathrm{~g}$ & & \\
Cinnamon & $0.2 \mathrm{~g}$ & & \\
\hline
\end{tabular}




\section{Results and Discussion}

\section{pH}

Table 2 shows the effect on $\mathrm{pH}$ of adding citrus fiber to both raw and cooked ground beef samples. The $\mathrm{pH}$ range of the raw samples ranged between 5.47 and 5.62 for treatments. Cooking caused a rise in the $\mathrm{pH}$ of all treatments except the CF $10 \%$ treatment. Similar results were also observed by Bilek and Turhan (2009). The $\mathrm{pH}$ range of the cooked samples ranged between 5.49 and 5.74 . Adding $10 \%$ citrus fiber caused a significant $(\mathrm{p}<0.05)$ change in the $\mathrm{pH}$ of the cooked samples. However, the change in the $\mathrm{pH}$ of treatments with $1 \%$ and $5 \%$ citrus fiber was not significant $(p>0.05)$ in comparison to change in the $\mathrm{pH}$ of the control.

\section{Water Holding Capacity (WHC) and Cooking Yield (CY\%)}

The addition of citrus fiber boosted both the WHC and cooking yield. Table 2 illustrates the impact of adding citrus fiber on the water holding capacity and cooking yield of ground beef meatball treatments. Besbes et al. (2008) reported that an increase in the addition of wheat fiber caused a rise in the water holding capacity of beef burgers in comparison to the control burger samples. Furthermore, the cooking yield of $\mathrm{CF} 10 \%$ was highest at 92.21 , and all the citrus treatments had significantly $(\mathrm{p}<0.05)$ higher cooking yields than the control (CF 0\%). Serdaroglu et al. (2005) found similar results with the use of lentil flours on improving the water holding capac-ity and cooking yield of low fat meatballs. Cengiz and Gokoglu (2007) also reported that the addition of citrus fiber reduced the cooking loss for frankfurter-type sausages. Since the citrus fiber is high in pectin, it can allow binding with free water from meat samples. Thus, it can help with improving water holding capacity and cooking yield.

\section{Determination of Moisture, Fat and Protein Content}

The moisture, fat and protein content of the ground beef treat-ments are shown in Table 2. The moisture content of the con-trol was highest, and an increase in the addition of the dry ingredient - citrus fiber-caused a decrease in the moisture content of all treatments. While the gradual decrease in mois-ture content was expected due to addition of dry powder in different levels, the major increase in the protein content was not expected. Even with the addition of $6.37 \%$ protein com-ing from citrus fiber, increase in the protein content was nor-mal than higher. This could be due to BCA colorimetric methodology. Smith et al. (1985) reported that presence of glucose caused artificially high protein content values. Kessler and Faneshil (1986) also reported that phospholipids can react with bicinchoninic acid (BCA) that can cause artificially high protein content. Since, citrus fiber has sugars, such as glucose that may interfere with our results and therefore it may cause artificially high protein content. Table 3 displays the nutritional facts associated with CitraFiber ${ }^{\mathrm{TM}}$ citrus fiber. Huang et al. (2011) reported similar results: The addition of wheat fiber into Chinese-style sausages caused a decrease in the moisture content and an increase in the protein content.

\section{Textural Properties}

The textural properties of ground beef meatballs made with or without citrus fiber are shown in Table 4. Our results showed that the addition of citrus fiber caused a decrease in hardness. The control had the highest hardness values, and there were no significant $(\mathrm{p}>0.05)$ differences between the control and CF $1 \%$. However, there were significant $(p<0.05)$ differences between treatments in terms of all of the textural properties. Yang et al. (2007) reported similar results: Adding hydrated oatmeal and tofu caused a decrease in the hardness of low-fat pork sausages. There were also reports of the hardening of meat products with the addition of fiber. Cofrades et al. (2000) stated that the addition of soy fiber caused an increase in the hardness of bologna-type sausage. Huang et al. (2011) also found hardening in Chinese-type sausages made with wheat or oat fiber. Most of the studies observed increase in hardness with addition of fiber were emulsified meat products. Springiness slightly decreased with the addition of citrus fiber, the significant difference $(p<0.05)$ was observed between the control and CF 5 and $10 \%$. The cohesiveness of ground beef meatballs made with $0 \%$ and $1 \%$ citrus fiber was significantly higher $(p<0.05)$ than the meatballs made with $5 \%$ and $10 \%$ citrus fiber. Samples made with $10 \%$ citrus fiber had less cohesiveness and resilience than those of other treatments.

\section{Hunter Color L, a, b Values}

Results of the Hunter color $L, a, b$ values are summarized in Table 5. The addition of citrus fiber caused significant $(p<0.05)$ decrease in lightness, redness and yellowness values for raw ground beef treatments. Only exception, there was no significant $(p>0.05)$ difference found between yellowness values for the control and the $\mathrm{CF} 10 \%$. The changes in color of treatments were visually apparent and can be seen by the Picture 1. Bilek and Turhan (2009) observed similar results, where the addition of flax seed flour caused a decrease in the 
lightness values of the beef patties made with $20 \%$ fat content. The control treatment redness values were significantly higher $(p<0.05)$ than all of the other treatments. The addition of citrus fiber caused a decrease in the redness values for raw ground beef samples. Fernandez-Gines et al. (2003) reported an increase in the redness values when citrus fiber was first added to bolognas but a decrease in the redness values during storage time. The addition of citrus fiber to raw ground beef significantly $(p<0.05)$ increased the $b$ values of all treatments.
While the addition of citrus fiber at $10 \%$ level had the highest yellowness values, it was not significantly $(\mathrm{p}>0.05)$ different than the control. Cofrades et al. (2000), and Cengiz and Gokoglu (2007) reported similar results: Increasing the addition of fiber caused a rise in $b$ values. The difference between our findings and those of prior studies could result from our product being raw and mixed ground beef whereas other studies were conducted with cooked emulsified products.

Picture 1. Hunter color measurement of raw ground beef treatments

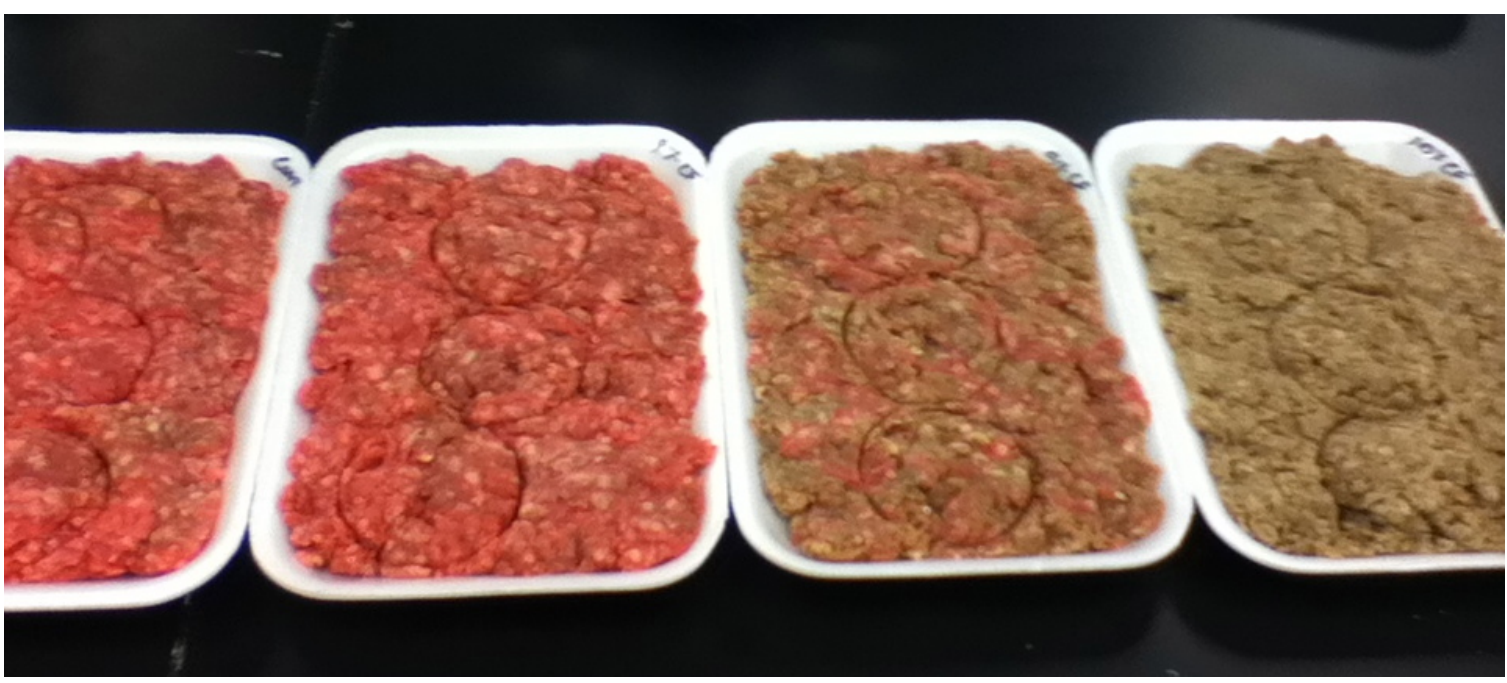

Table 2. Addition of different levels of citrus fiber on physico-chemical properties of ground beef meatballs

\begin{tabular}{llccc}
\hline & \multicolumn{3}{c}{ Citrus Fiber Treatment Levels } \\
\cline { 2 - 5 } & \multicolumn{1}{c}{$0 \%$} & $1 \%$ & $5 \%$ & $10 \%$ \\
\hline pH raw & $5.54 \pm 0.139^{\mathrm{ab}}$ & $5.62 \pm 0.133^{\mathrm{a}}$ & $5.59 \pm 0.096^{\mathrm{a}}$ & $5.47 \pm 0.104^{\mathrm{b}}$ \\
pH cooked & $5.65 \pm 0.100^{\mathrm{a}}$ & $5.74 \pm 0.136^{\mathrm{a}}$ & $5.66 \pm 0.104^{\mathrm{a}}$ & $5.49 \pm 0.121^{\mathrm{b}}$ \\
WHC & $0.68 \pm 0.13^{\mathrm{a}}$ & $0.49 \pm 0.05^{\mathrm{b}}$ & $0.44 \pm 0.09^{\mathrm{bc}}$ & $0.36 \pm 0.07^{\mathrm{c}}$ \\
Cooking Yield (\%) & $71.43 \pm 4.54^{\mathrm{c}}$ & $78.91 \pm 4.64^{\mathrm{b}}$ & $86.62 \pm 4.54^{\mathrm{a}}$ & $92.21 \pm 4.79^{\mathrm{a}}$ \\
Moisture Content (\%) & $60.75 \pm 2.51^{\mathrm{a}}$ & $60.51 \pm 2.14^{\mathrm{a}}$ & $58.49 \pm 1.86^{\mathrm{ab}}$ & $56.35 \pm 3.88^{\mathrm{b}}$ \\
Fat Content (\%) & $21.30 \pm 3.01^{\mathrm{a}}$ & $20.59 \pm 2.76^{\mathrm{ab}}$ & $19.81 \pm 2.90^{\mathrm{b}}$ & $19.68 \pm 3.26^{\mathrm{b}}$ \\
Protein Content (\%) & $14.46 \pm 0.69^{\mathrm{d}}$ & $16.49 \pm 0.49^{\mathrm{c}}$ & $19.28 \pm 0.81^{\mathrm{b}}$ & $21.16 \pm 0.64^{\mathrm{a}}$ \\
\hline
\end{tabular}

Each value in the Table is represented as mean \pm standard deviation $(\mathrm{n}=6)$.

$\mathrm{a}, \mathrm{b}, \mathrm{c}, \mathrm{d}$ Different superscripts in the same row indicate significant difference by the Tukey`s test $(\mathrm{p}<0.05)$. 
Table 3. Nutritional facts about citrus fiber CitraFiber ${ }^{\mathrm{TM}}$

\begin{tabular}{ll}
\hline Total Pectin & $9390 \mathrm{mg} / 100 \mathrm{~g}$ \\
Protein & $6.37 \%$ \\
Total Sugars & $1.7 \%$ \\
Total Dietary Fiber & $82.7 \%$ \\
Soluble Fiber & $23.4 \%$ \\
Insoluble Fiber & $59.3 \%$ \\
Potassium & $453 \mathrm{mg} / 100 \mathrm{~g}$ \\
Sodium & $210 \mathrm{mg} / 100 \mathrm{~g}$ \\
Calcium & $78 \mathrm{mg} / 100 \mathrm{~g}$ \\
Vitamin A (Beta Carotene) & $117 \mathrm{IU} / 100 \mathrm{~g}$ \\
Vitamin C & $0.91 \mathrm{mg} / 100 \mathrm{~g}$ \\
\hline
\end{tabular}

Source: Natural Citrus Products

Table 4. Addition of different levels of citrus fiber on textural properties of ground beef meatballs

\begin{tabular}{|c|c|c|c|c|c|c|}
\hline \multirow{2}{*}{$\begin{array}{l}\text { Citrus } \\
\text { Fiber } \\
\text { Levels }\end{array}$} & \multicolumn{6}{|c|}{ Textural Properties } \\
\hline & Hardness & $\begin{array}{l}\text { Springi- } \\
\text { ness }\end{array}$ & $\begin{array}{l}\text { Cohesive- } \\
\text { ness }\end{array}$ & Gumminess & Chewiness & Resilience \\
\hline \multirow{2}{*}{ CF 0\% } & 1356.13 & 0.746 & 0.553 & 743.90 & 563.01 & 0.228 \\
\hline & $\pm 500.65^{\mathrm{a}}$ & $\pm 0.051^{\mathrm{a}}$ & $\pm 0.036^{\mathrm{a}}$ & $\pm 252.42^{\mathrm{a}}$ & $\pm 221.8^{\mathrm{a}}$ & $\pm 0.021^{\mathrm{a}}$ \\
\hline \multirow[t]{2}{*}{ CF $1 \%$} & 1088.89 & 0.714 & 0.480 & 521.59 & 378.63 & 0.194 \\
\hline & $\pm 396.29^{\mathrm{ab}}$ & $\pm 0.051^{\mathrm{a}}$ & $\pm 0.03^{\mathrm{b}}$ & $\pm 179.94^{\mathrm{b}}$ & $\pm 150.78^{b}$ & $\pm 0.019^{\mathrm{b}}$ \\
\hline \multirow[t]{2}{*}{ CF 5\% } & 887.17 & 0.656 & 0.346 & 304.06 & 201.22 & 0.145 \\
\hline & $\pm 243.74^{\mathrm{b}}$ & $\pm 0.046^{\mathrm{b}}$ & $\pm 0.052^{\mathrm{c}}$ & $\pm 78.86^{\mathrm{c}}$ & $\pm 59.97^{\mathrm{c}}$ & $\pm 0.019^{\mathrm{c}}$ \\
\hline \multirow[t]{2}{*}{ CF $10 \%$} & 819.69 & 0.611 & 0.244 & 198.62 & 120.83 & 0.121 \\
\hline & $\pm 246.72^{\mathrm{b}}$ & $\pm 0.05^{\mathrm{c}}$ & $\pm 0.074^{\mathrm{d}}$ & $\pm 76.31^{\mathrm{c}}$ & $\pm 46.79^{\mathrm{c}}$ & $\pm 0.023^{\mathrm{d}}$ \\
\hline
\end{tabular}

Each value in the Table is represented as mean \pm standard deviation $(n=9)$.

a, b, c,d Different letters in the same column indicate a significant difference by the Tukey`s test $(p<0.05)$.

Table 5. Effect of citrus fiber on hunter color $L, a, b$ values of raw ground beef treatments

\begin{tabular}{llll}
\hline $\begin{array}{l}\text { Citrus Fiber } \\
\text { Levels }\end{array}$ & $L$ Value & $\begin{array}{l}\text { Hunter Color } \\
\text { Value }\end{array}$ & $b$ Value \\
\hline CF 0\% & $48.24 \pm 0.742^{\mathrm{a}}$ & $23.36 \pm 1.01^{\mathrm{a}}$ & $9.98 \pm 0.240^{\mathrm{a}}$ \\
CF 1\% & $44.42 \pm 0.117^{\mathrm{bc}}$ & $18.64 \pm 0.96^{\mathrm{b}}$ & $9.35 \pm 0.177^{\mathrm{b}}$ \\
CF 5\% & $42.92 \pm 0.801^{\mathrm{c}}$ & $11.89 \pm 2.10^{\mathrm{c}}$ & $9.39 \pm 0.164^{\mathrm{b}}$ \\
CF $10 \%$ & $45.61 \pm 0.848^{\mathrm{b}}$ & $8.23 \pm 2.28^{\mathrm{c}}$ & $10.29 \pm 0.268^{\mathrm{a}}$ \\
\hline
\end{tabular}

Each value in the Table is represented as mean \pm standard deviation $(n=9)$.

a, b, c, d Different letters in the same column indicate a significant difference by the Tukey's test $(p<0.05)$. 


\section{Sensory Evaluation of Meatballs}

Consumers' acceptance of ground beef meatballs made with different levels of citrus fiber is shown in Table 6. Results showed that meatballs made with $1 \%$ citrus fiber (CF $1 \%$ ) had the highest flavor score with 6.61 , followed by the control treatment with 6.52 . There was no significant difference ( $p>0.05$ ) in flavor scores between CF $1 \%$ and the control treatment, however, both treatments had significantly $(p<0.05)$ higher flavor scores than $\mathrm{CF} 3 \%$ and $\mathrm{CF} 5 \%$. Besbes, Attia, Deroanne, Makni, and Blecker (2008) reported similar results. Beef burgers made with pea and wheat fiber received the highest flavor scores. In another study, YildizTurp and Serdaroglu (2010) reported that low fat beef patties made with $10 \%$ plum puree received higher flavor scores than the control. On the other hand, Bilek and Turhan (2009) reported that the addition of flaxseed flour to beef patties caused a decrease in flavor scores.

Results showed that texture attribute of ground beef meatballs were significantly $(\mathrm{p}<0.05)$ impacted by the addition of citrus fiber. The control meatball treatments received the highest scores of 6.69 , followed by the CF $1 \%$ treatment with 6.27 . Treatments with the highest citrus fiber, the CF 5\%, received the lowest score in texture with 5.46, which is like slightly. Besbes et al. (2008); Bilek and Turhan (2009) reported similar results: an increase in the fiber levels caused a decrease in texture sensory scores for beef patties. There were also reports of improvements in sensory texture scores for sausage products. Huang, Tsai, and Chen (2011) reported that Chinese style sausages made with oat fiber received higher scores than the control. Yalinkilic et al. (2012) reported that a fermented sausage product called Sucuk made with citrus fiber received slightly higher sensory texture results than the control.

Results of overall likeness for the four treatment groups are shown in Table 6. The control has the highest overall likeness scores with 6.69 followed by the CF $1 \%$ with 6.56 , the CF $3 \%$ with 5.9 and the CF 5\% with 5.47. There was no significant $(p>0.05)$ difference in overall likeness scores between the control and the CF 1\%. However, there were significant $(\mathrm{p}<0.05)$ differences between the control with the CF 3\% and the CF 5\%. Fernadez-Gines, Fernandez-Lopez, SayasBarbera, Sendra, and Perez-Alvarez (2003) reported similar findings. They found that, at the highest concentration, the addition of citrus fiber to bolognas caused a decrease in overall quality scores. Serdaroglu et al. (2005) reported that meatballs made with legume flour extenders received high scores (6.8 and above) in overall acceptability. Additionally, in another study low fat pork sausage made with oatmeal or tofu received higher overall acceptability scores than control pork sausages (Yang, Choi, Jeon, Park, \& Joo, 2007). In a recent study, Tomaschunas et al. (2013) reported that low fat Lyon style sausages made with inulin and citrus fiber had similar sensory characteristics to full fat reference.

Table 6. Consumers' acceptance of Turkish meatballs made with different levels of citrus fiber

\begin{tabular}{llll}
\hline Citrus Fiber Levels & Flavor & Texture & Overall Likeness \\
\hline \hline CF 0 \% & $6.52 \pm 1.4^{\mathrm{a}}$ & $6.69 \pm 1.52^{\mathrm{a}}$ & $6.69 \pm 1.37^{\mathrm{a}}$ \\
CF 1 \% & $6.61 \pm 1.44^{\mathrm{a}}$ & $6.27 \pm 1.75^{\mathrm{b}}$ & $6.55 \pm 1.51^{\mathrm{a}}$ \\
CF 3 \% & $5.94 \pm 1.76^{\mathrm{b}}$ & $5.9 \pm 1.67^{\mathrm{c}}$ & $5.9 \pm 1.66^{\mathrm{b}}$ \\
CF 5\% & $5.49 \pm 1.73^{\mathrm{c}}$ & $5.46 \pm 1.89^{\mathrm{d}}$ & $5.47 \pm 1.68^{\mathrm{c}}$ \\
\hline
\end{tabular}

Each value in the Table is represented as mean \pm standard deviation.

a, b, c, d Different letters in the same column indicates significant difference $(p<0.05)$ analyzed by the Tukey`s test. 


\section{Conclusion}

Results of this study indicate that citrus fiber at $1 \%$ level can be used in comminuted meat products to increase the cooking yield and water holding capacity, and it can have high acceptability by the consumer. Both industry and consumers can benefit from using citrus fiber in meat products.

\section{Compliance with Ethical Standard}

Conflict of interests: The authors declare that for this article they have no actual, potential or perceived the conflict of interests.

\section{References}

Akoh, C. (1998). Fat replacers. Food Technology, 52(3), 4753.

Aleson-Carbonell, L., Fernandez-Lopez, J., Perez-Alvarez, J., Kuri, V. (2005). Functional and sensory effects of fiber rich ingredients on breakfast freash sausage manufacture. International Journal of Food Science \& Technology 11(2), 89-97.

https://doi.org/10.1177/1082013205052003

Besbes, S., Attia, H., Deroanne, C., Makni, S., Blecker, C. (2008). Partial replacement of meat by pea fiber and wheat fiber: Effect on the chemical composition, cooking characteristics and sensory properties of beef burgers. Journal of Food Quality, 31, 480-489.

https://doi.org/10.1111/j.1745-4557.2008.00213.x

Bilek, E.A., Turhan, S. (2009). Enhancement of the nutritional status of beef patties by adding flaxseed flour. Meat Science, 82, 472-477.

https://doi.org/10.1016/j.meatsci.2009.03.002

PMid:20416676

Bishop, D.J., Olson, D.G., Knipe, C.L. (1993). Pre-emulsified corn oil, pork fat, or added moisture affect quality of reduced fat bologna quality. Journal of Food Science, 58(3), 484-487.

https://doi.org/10.1111/j.1365-2621.1993.tb04306.x

Choi, Y.S., Choi, J.H., Han, D.J., Kim, H.Y., Lee, M.A., Jeong, J.Y., Chung, H.J., Kim, C. J. (2010). Effects of replacing pork back fat with vegetable oil and rice bran fiber on the quality of reduced-fat frankfurters. Meat Science, 84, 557563. https://doi.org/10.1016/j.meatsci.2009.10.012

PMid:20374824

Cross, A., Leitzmann, M., Gail, M. (2007). The impact of dietary and lifestyle risk factors on risk of colorectal cancer: A quantitative overview of the epidemiological evidence. International Journal of Cancer, 125, 171-180. https://doi.org/10.1002/ijc. 24343

PMid:19350627

Fernadez-Gines, J.M., Fernandez-Lopez, J., Sayas-Barbera, E., Sendra, E., Perez-Alvarez, J.A. (2003). Effect of storage conditions on quality characteristics of bologna sausages made with citrus fiber. Journal of Food Science, 68(2), 710-715.

https://doi.org/10.1111/j.1365-2621.2003.tb05737.x

Fernandez-Lopez, J., Fernandez-Gines, J.M., AlesonCarbonell, L., Sendra, E., Sayas-Barbera, E., Perez-Alvarez, J. A. (2004). Application of functional citrus by-products to meat products. . Trends in Food Science and Technology, $15,176-185$.

https://doi.org/10.1016/j.tifs.2003.08.007

Grigelmo-Miguel, N., Motilva-Casado, M.J., Martin-Belloso, O. (1997). Characterisation of low-fat frankfurters using peach dietary fiber as an ingredient. In: Book of abstracts. Institute of Food Technologists Annual Meeting, 23E-15.

Huang, S.C., Tsai, Y.F., Chen, C.M. (2011). Effects of wheat fiber, oat fiber and inulin on sensory and physicochemical properties of chinese-style sausages. Asian Australasian Journal of Animal Science, 24(6), 875-880.

https://doi.org/10.5713/ajas.2011.10317

IFT (1981). Sensory evaluation guide for testing food and beverage products. Journal of Food Science, 11, 50-59.

Kritchersky, D. (1990). Dietary fiber. In I. Furda \& C. Brine (Eds.), A glance into the future: New developments in dietary fiber. NY: Plenium Press.

https://doi.org/10.1007/978-1-4684-5784-1_ 1

PMid:1963999

Lajous, M., Tondeur, L., Fagherazzi, G., Lauzon-Guillain, B., Boutron-Ruaualt, M., Clavel-Chapelon, F. (2011). Processed and unprocessed red meat consumption and incident of type 2 diabetes among French women. Diabetes Care, 35(1), 128-130.

https://doi.org/10.2337/dc11-1518

PMid:22100967 PMCid:PMC3241336 
Larsson, S., Virtamo, J., Wolk, A. (2011). Red meat consumption and risk of stroke in Swedish men. The American Journal of Clinical Nutrition, 94, 417-421.

https://doi.org/10.3945/ajen.111.015115

PMid:21653800

Lopez-Vargas, J. H., Fernandez-Lopez, J., Perez-Alvarez, J.A., Viuda-Martos, M. (2014). Quality characteristics of pork burger added with albedo-fiber powder obtained from yellow passion fruit (Passiflora edulis var. flavicarpa) coproducts. Meat Science, 97(2), 270-276.

https://doi.org/10.1016/j.meatsci.2014.02.010

PMid:24607997

Micha, R., Wallace, S., Mozaffarian, D. (2010). Red and processed meat consumption and risk of incident coronary hearth disease, stroke, and diabetes mellitus: A systematic review and meta analysis. Circulation, 121, 2271-2283. https://doi.org/10.1161/CIRCULATIONAHA.109.924977

PMid:20479151 PMCid:PMC2885952

Rosamond, W., Flegal, K., Furie, K., Go, A., Greenlund, K., Haase, N., Hailpern, S.M., Ho, M., Howard, V., Kissela, B., Kittner, S., Lloy-Jones, D., McDermott, M., Meigs, J., Moy, C., Nichol, G., O`Donnell, C., Roger, V., Sorlie, P., Steinberger, J., Thom, T., Wilson, M., Hong, Y. (2008). American hearth association statistical update. Circulation, 29(January), e25-e146.

https://doi.org/10.1161/CIRCULATIONAHA.107.187998

SAS (2011). Base SAS 9.3 Procedures Guide. Base SAS 9.3 Procedures Guide: SAS Institute Inc.

http://support.sas.com/documenta-

tion/cdl/en/proc/65145/HTML/default/viewer.htm\#ti-

tlepage.htm (accessed 03.11.2018).

Scheneeman, B.O. (1987). Soluble vs insoluble fiber-different physiological responses. Food Technology, 41, 81-82.

Serdaroglu, M., Yildiz-Turp, G., Abrodimov, K. (2005). Quality of low-fat meatballs containing legume flours extenders. Meat Science, 70, 99-105.

https://doi.org/10.1016/j.meatsci.2004.12.015

PMid:22063285

Singh, P., Kumar, R., Sabapathy, S., Bawa, A. (2008). Functional and edible uses of soy protein products. Compre- hensive Reviews in Food Science and Food Safety, 7, 14-28. https://doi.org/10.1111/j.1541-4337.2007.00025.x

Soncu, E.D., Kolsarici, N., Cicek, N., Ozturk, G.S., Akoglu, I.T., Arici, Y.K. (2015). The comparative effect of carrot and lemon fiber as a fat replacer on physico-chemical, textural, and organoleptic quality of low-fat beef hamburgers. Korean Journal of Food Science of Animal Resources, 35(3), 370-381.

https://doi.org/10.5851/kosfa.2015.35.3.370

PMid:26761851 PMCid:PMC4662360

Tomaschunas, M., Zorb, R., Fischer, J., Kohn, E., Hinrichs, J., Busch-Stockfisch, M. (2013). Changes in sensory properties and consumer acceptance of reduced fat pork Lyon-style and liver sausages containing inulin and citrus fiber as fat replacers. Meat Science, 95(3), 629-640.

https://doi.org/10.1016/j.meatsci.2013.06.002

PMid:23811098

USDHHS (1997). Health claims: Oats and coranary hearth disease-final rule. Federal Registry, 62, 3583-3601.

USDHHS (1998). Health claims: Soluble fiber from certain foods and coronary hearth disease- final rule. Federal Registry, 63, 8103-8121.

Yalinkilic, B., Kaban, G., Kaya, M. (2012). The effects of different levels of orange fiber and fat on microbiological, physical, chemical and sensorial properties of sucuk. Food Microbiology, 29, 255-259.

https://doi.org/10.1016/j.fm.2011.07.013

PMid:22202881

Yang, H.S., Choi, S.G., Jeon, J.T., Park, G.B., Joo, S.T. (2007). Textural and sensory properties of low fat pork sausages with added hydrated oatmeal and tofu as texture modifynig agent. Meat Science, 75, 283-289.

https://doi.org/10.1016/j.meatsci.2006.07.013

PMid:22063660

Yildiz-Turp, G., Serdaroglu, M. (2010). Effects of using plum puree on some properties of low fat beef patties. Meat Science, 86, 896-900. https://doi.org/10.1016/j.meatsci.2010.07.009

PMid:20732751 